\title{
Analysis of Factors That Affect Consumer Preference on Coffee Consumption in Surabaya
}

\author{
Sudiyarto ${ }^{1}$, Resti Prastika Destiarni, Gyska Indah Harya \\ Department of Agribusiness \\ Universitas Pembangunan Nasional "Veteran" Jawa Timur \\ Surabaya, Indonesia \\ ${ }^{1}$ sentotsudiyarto@yahoo.com
}

\begin{abstract}
There are two variants of processed coffee, there are brewed coffee and instant coffee. Each coffee have their own consumers. The difference of consumer preference on coffee consumption led to research idea about factors that affecting consumer preference on coffee consumption. This research was conducted to determine factors that affecting consumer preference on consuming between brewed coffee and instant coffee by the case study was taken in Surabaya. Factors that affecting preference of coffee selection are gender, age, last education, coffee drinking experience, early age of coffee consumption, and number of family members. With number of respondents equal to 57 respondents, this research would be analyzed by using logistic regression to determine the opportunity of which coffee were preferred by consumers. Based on parameter estimation result, four variables had a significant effect, there were gender, last education, drinking coffee experience, and number of family members. The four independent variables could explain the model of coffee consumer preference around 51 percent. Opportunities of adult male, with high school education level; drinking coffee experience around 11 - 20 years; and number of families were more than five, consumed instant coffee around 0.13. Unlike the female consumer who preferred consuming instant coffee with opportunities was around 0.81 to brewed coffee. Producers have to be able to see that the calculation is an opportunity for them to differentiate their owned coffee product. Coffee producers can compete by making product innovation which could be affordable to all consumers both male and female.
\end{abstract}

\section{Keyword-coffee; consumer preference; logistic regression}

\section{INTRODUCTION}

Indonesia is one of the largest coffee producers in the world with its production number placing Indonesia fourth behind Brazil, Vietnam and Colombia [1]. Coffee is one of the plantation commodities that contribute foreign exchange to Indonesia from its export activities. The Ministry of Agriculture's strategic plan in terms of increasing production does not only focus on the staple food source commodities but includes four other commodities originating from the plantation sub-sector, one of which is coffee. The economic value of coffee commodities is estimated to reach Rp 17 trillion so that it makes coffee play an important role in the Indonesian economy and is the number four commodity that contributes to Indonesia's trade balance [2-5] There are two types of coffee that are cultivated in Indonesia, namely
Arabica coffee and Robusta coffee, with the majority of cultivation being robusta coffee [9].

The area for robusta coffee cultivation reaches 912,135 ha while for arabica coffee cultivation reaches 321,158 ha $[6,9]$. In addition to arabica and robusta coffee, in the international market Indonesia is known for its specialty coffee and the coffee market began to grow rapidly $[7,8]$ Specialty coffee in Indonesia arises because of differences in the topography of the area of coffee plantations and the different tastes of Indonesian people in consuming coffee. There are 10 types of specialty coffee in Indonesia that have registered their geographical indices, namely Arabo Gayo Coffee, Sumatra Arabica Coffee Simalungun, Lampung Robusta Coffee, Java Preanger Arabica Coffee, Sindoro Sumbing Arabica Coffee, Java Arabica Coffee Ijen Raung, Kintamani Bali Arabica Coffee, Bajawa Arabica Coffee Flores, Kalosi Enrekang Arabica Coffee, and Toraja Arabica Coffee [9].

Geographical index is a form of protection provided in relation to a product that shows the place of origin of the region, the quality or characteristics of the product that are specific, and the quality due to geographical or human conditions [9].

Coffee is a popular commodity with processed products in the community both at home and abroad [10]. Coffee is a trading material because it can be processed into a delicious drink, refreshes the body, and can relieve drowsiness [11]. In Indonesia, the level of coffee consumption in 2015 reached 896 grams/capita/ year [6]. Based on data obtained from ICO (International Coffee Organization), Indonesia is among the top five countries with the largest coffee consumption in the world in the period 2010-2015 with an average increase in coffee consumption reaching 2-5 percent per year.

In Indonesia, there are six provinces which are coffee production centers, with the majority of companies being smallholder plantations, namely South Sumatra, Lampung, North Sumatra, Bengkulu, Aceh, and East Java with the only types of coffee cultivated, namely robusta, arabica, and both types of coffee. In East Java province alone, coffee commodities that are more cultivated are robusta coffee. Indonesian people in general and East Java in particular have a habit of drinking coffee every day. Many circles with various kinds of social status favor coffee with a variety of 
consumption purposes, both for consumption of beverages in general, which are related to consumptive nature and changes in people's lifestyles [12-14] as well as for consumption related to health, among others, to prevent neurological diseases, reduce the risk of breast cancer, prevent diabetes, and efficacious revitalize new skin cells [15-20]

Based on the type, processed coffee on the market has two types of brewed coffee and instant coffee. Each type of coffee has its own consumers [23]. The brewed coffee consumers are those who like the distinctive taste of coffee, can be mixed and brewed according to taste (thick or runny) [21, 22] while instant coffee consumers are those who like practicality [2325]. Differences in consumer preferences in consuming coffee give rise to research ideas about factors that influence consumer preferences in consuming coffee [30, 39]. Food product preferences are plastic and will be permanent if someone has a stronger lifestyle. A marketer must be able to understand and adapt consumer preferences and behavior as an absolute necessity for competitive continuity because consumers are the holders of control and marketers can be said to be successful if the product is seen as offering real benefits [26]. This study was conducted to determine factors that influence consumer preferences in consuming between instant coffee or instant coffee [23-25].. This research is expected to be a view for businesses in understanding consumer desires and planning the development of their businesses [30, 39].

\section{RESEARCH METHODS}

The case study of this study was taken in the city of Surabaya with the consideration that drinking coffee has become a lifestyle not only among adults but also in young people [25-28] and the development of coffee processing industries in the City Surabaya every year. Factors influencing coffee selection preferences are gender [29-31], age [32,33], recent education [34,35], coffee drinking experience [36], [37], the early age of coffee consumption [38], and the number of family members $[39,40]$. The sampling method used was purposive sampling because the sampling of consumers based on certain considerations saw not all samples matched the criteria studied [41]. The number of samples taken was 57 respondents of coffee consumers with consideration of the variables used as many as six variables multiplied by five times [42]. Data collection was carried out by interviewing each respondent who was a coffee consumer using a questionnaire.

This study will be analyzed using logistic regression to see factors that influence consumer preferences in consuming instant coffee or instant coffee from the opportunities [23-25].

TABLE I. VARIABLES IN LOGISTIC REGRESSION MODELS

\begin{tabular}{|c|c|l|}
\hline Variable & Variable Name & \multicolumn{1}{|c|}{ Variable Scale } \\
\hline \multirow{2}{*}{ Y } & Coffee & $\begin{array}{l}0=\text { Brewed Coffee } \\
1=\text { Instant Coffee }\end{array}$ \\
\hline \multirow{4}{*}{ X } & Gender & $\begin{array}{l}0=\text { Woman } \\
1=\text { Man }\end{array}$ \\
\cline { 2 - 3 } & Age (year) & $\begin{array}{l}0=18-40 \text { (adult) } \\
1=41-65 \text { (old) }\end{array}$ \\
\cline { 2 - 3 } & Recent Education & $0=$ SMP \\
\cline { 2 - 3 }
\end{tabular}

\begin{tabular}{|c|c|l|}
\hline Variable & Variable Name & \multicolumn{1}{|c|}{ Variable Scale } \\
\hline \multirow{4}{*}{ Coffee Drinking Experience } & $1=$ SMA \\
& & $2=$ Perguruan Tinggi \\
\cline { 2 - 3 } & & $0=0-10$ \\
(year) & $3=21-20$ \\
& $3=31-40$ \\
& $4=41-50$ \\
\cline { 2 - 3 } & Early Age of Coffee & $0=12-17$ \\
Consumption & $1=18-40$ \\
\cline { 2 - 3 } & Family Members & $0=<5$ \\
& & $1=\geq 5$ \\
\cline { 2 - 2 }
\end{tabular}

Based on table 1, we can see independent variables, dependent variables, and measurement scales of each variable.

An econometric approach using logistic regression is a statistical analysis method to describe the relationship between dependent variables that have two or more categories with one or more category or interval-scale independent variables $[43,44]$. Logistic regression is used to explain the non-linear variables $\mathrm{X}$ and $\mathrm{Y}, \mathrm{Y}$ distribution abnormalities, not constant variation in responses which cannot be explained by ordinary linear regression models [45]. An ordinary linear regression model with an OLS (ordinary least square) approach cannot explain the relationship between variables $\mathrm{X}$ and $\mathrm{Y}$ if variable $\mathrm{X}$ has two or more categories and variable $\mathrm{Y}$ has qualitative or categorical properties. If the variable is forced to use linear regression method, there will be a violation of the assumption of Gauss-Markov [46]. The violation of the Gauss-Markov assumption is the regression model error does not spread normally and the error range is not homogeneous (heteroscedasticity occurs) while the violation of the estimation value $\mathrm{Y}$ is the estimated value of the linear regression model that exceeds the range $0-1$ even though the categorical response variable value is one and zero [38, 47].

$$
\operatorname{Logit}(\mathrm{Y})=\text { Natural } \log (\text { odds })=\ln \left(\frac{\pi}{\pi-1}\right)=\alpha+\beta \text { XLo }
$$

Logistic regression of binary logistics and multinomial logistics. The relationship between $\mathrm{Y}$ variables that dichotomic scale on one or more $\mathrm{X}$ variables while multinomial logistic regression is used to analyze the relationship between $\mathrm{Y}$ variables that have more than one category against one or more variables $\mathrm{X}$. Logistic regression models can be written as follows $[48,49]$ :

$$
\pi_{\mathrm{i}}=\frac{1}{1+\mathrm{e}^{-\left(\mathrm{a}+\sum_{\mathrm{f}=1}^{\mathrm{n}} \beta_{1} \mathrm{X}_{\mathrm{ji}}+\sum_{\mathrm{k}=1}^{\mathrm{m}} \gamma_{\mathrm{k}} \mathrm{D}_{\mathrm{kt}}\right)}}
$$

The model is a simple model of [50], Example:

$$
\left(\mathrm{a}+\sum_{\mathrm{f}=1}^{\mathrm{n}} \beta_{1} \mathrm{X}_{\mathrm{ji}}+\sum_{\mathrm{k}=1}^{\mathrm{m}} \gamma_{\mathrm{k}} \mathrm{D}_{\mathrm{kt}}\right)=\mathrm{z}
$$

Then the logistic equation model equation (1) can be written: 


$$
\pi_{\mathrm{i}}=\frac{1}{1+\mathrm{e}^{-\mathrm{z}}}
$$

From model equation (2) can be written:

$$
1-\pi_{\mathrm{i}}=1-\frac{1}{1+\mathrm{e}^{-\mathrm{z}}}
$$

So that

$$
\frac{\pi_{\mathrm{i}}}{\left(1-\pi_{1}\right)}=\frac{1+\mathrm{e}^{-\mathrm{z}}}{\left(1+\mathrm{e}^{-\mathrm{z}}\right) \mathrm{e}^{-\mathrm{z}}}=\mathrm{e}^{\mathrm{z}}
$$

The transformation of equation (4) is:

$$
\operatorname{Ln} \frac{\pi_{\mathrm{i}}}{\left(1-\pi_{\mathrm{i}}\right)}=\alpha+\sum_{\mathrm{j}=1}^{\mathrm{n}} \beta_{\mathrm{i}} \mathrm{X}_{\mathrm{ji}}+\sum_{\mathrm{k}=1}^{\mathrm{m}} \mathrm{Y}_{\mathrm{k}} \mathrm{D}_{\mathrm{ki}}+\mathrm{e}
$$

Logistic regression modeling with predetermined independent and bound variables is:

$$
\operatorname{Ln} \frac{\pi_{\mathrm{i}}}{\left(1-\pi_{\mathrm{i}}\right)}=\alpha+\beta_{1}+\beta_{2}+\beta_{3}+\beta_{4}+\beta_{5}+\beta_{6}
$$

with,

$1=$ Gender

2 = Age

3 = Recent Education

4 = Coffee Drinking Experience

5 = Early Age Consumption

6 = Family Members

Estimation of logistic regression in the discussion of this study was completed with the maximum likelihood estimation method using the SPSS program.

When modeling with logistic regression has been done, the next step is to conduct a series of tests to show that the models and variables contained in the model are worth studying.

The feasibility test of the model is done to see that the model used is feasible or meets the GoF (goodnessof fit) criteria. A model is categorized as fulfilling the GoF if there is a match between the data contained in the model and the data observed [47]. There are three ways to test GoF in logistic regression, namely Pearson, deviance, and hosmer - lameshow methods. The use of Pearson method is based on Pearson test statistics with the rules of the decision are:

$\mathrm{H}_{0}$ is refused if $X_{h i t}^{2}>X_{\alpha}^{2}$ with $\alpha$ is $n-p$ which is a degree of freedom, $n$ is the number of groups and $p$ indicates the number of parameters in the explanatory variables [20]. The use of the deviance method is based on likelihood criteria by comparing models without explanation of the model with explanations with the rules of the decision are:

Refuse $\mathrm{H}_{0}$ if $D_{\text {hit }}^{2}>X_{\alpha}^{2}$ with $\alpha$ is $\mathrm{n}-\mathrm{p}$ which is a degree of freedom.
The use of the hosmer - lameshow method is carried out on the basis of grouping the value of the alleged opportunity that spreads $X^{2}$ with the rules of the decision are:

Refuse $\mathrm{H}_{0}$ if $C_{h i t}^{2}>X_{\alpha}^{2}$ with $\alpha$ is $g-2$ which is a degree of freedom. A model is categorized as feasible to meet GoF if the results of the hosmer - lameshow test are $<0.05$ [51].

After the model meets the $G o F$, then the real level test will be carried out on the model variables both partially and simultaneously. To perform a real-level test, logistic regression using $\mathrm{G}$ test or Omnibus Test of Model Coefficient and $W$ (Wald) test. Both tests are analogous to $F$ test and $T$ test in multiple linear regression. The $G$ test is conducted to determine the effect of independent variables that are used simultaneously or together. The $G$ Test Hypothesis is:

$$
H_{0}=\beta_{1}=0
$$

The $G$ test follows the distribution of $X^{2}$ with degrees of freedom $p$. Rules for declining decision $H_{0}$ are taken if $G_{h i t}^{2}>X_{\alpha}^{2}$, if $H_{0}$ is refused, meaning that the model is significant at the significance level $\alpha$.

In addition to using the $G$ test, simultaneous logistic regression can see the Omnibus Test of Model Coefficient value with the hypothesis (7).

Decision decision rule $\mathrm{HO}$ is the independent variable on the model simultaneously influencing the logistic regression model at the significance level $\alpha$ and is seen if the significance value of Omnibus Test of Model Coefficient is less than $\alpha$.

The $\mathrm{W}$ test is conducted to determine the effect of the independent variables used partially on the model. The $W$ test hypothesis same as equation (7).

The $\mathrm{W}$ test follows the standard normal distribution with the rules of the $H_{0}$ refusal decision taken if $\left|W_{h i t}\right|>Z_{\alpha / 2}$, if $H_{0}$ is rejected then the parameter is significant at the significance level $\alpha$.

Interpreting the coefficients in the logistic regression model is based on the Odds ratio coefficient (risk comparison). If an explanatory variable has a positive sign, then the Odds ratio will be greater than one, otherwise if the coefficient is negative then the Odds ratio will be smaller than one [52]. Odds ratio is written:

$$
\operatorname{odds}(\psi)=\frac{\pi_{i}}{1-\pi_{i}}
$$

Odds ratio is an indicator of a person's tendency to do or not to do activities. Odds of an event are defined as the probability that the results that appear are divided by the probability of an event not occurring.

$$
\psi=\frac{\operatorname{odds} A}{\operatorname{odds} B}=\left[\frac{\pi_{A} /\left(1-\pi_{A}\right)}{\pi_{B} /\left(1-\pi_{B}\right)}\right]
$$




\section{RESULTS AND DISCUSSION}

Consumers who are respondents are consumers who live in the city of Surabaya and have consumed both brewed coffee and instant coffee [23, 29, 30]. Even though they have consumed both coffees, the consumers chosen have a tendency, whether they tend to consume brewed coffee or consume instant coffee [23]. The regression model that will be used has been modeled in equation (6).

The regression model will be tested for goodness of fit, simultaneous test, and partial test to see the best model used with the existence of six independent variables or a reduction in variables because there are variables that are not significant so that they are excluded from the model. The level of significance used is 5 percent $(\alpha=0.05)$ [2, 6, 24, 28, 50].

TABLE II. Six VARIAble GoOdness of Fit (GOF) Test Results

\begin{tabular}{cccc}
\hline Step & Chi-square & df & Sig. \\
\hline 1 & 4.039 & 7 & .775 \\
\hline
\end{tabular}

Based on the GoF test results can be seen the significance value of hosmer and lameshow test is 0.775 at the level of $\alpha=$ 0.05 so that based on the hypothesis, accept H0, which indicates that the model is fit or feasible to use because there is no difference between the model and observation. The next test is testing the variables simultaneously by looking at the value of the omnibus test.

TABle III. Simultaneous Variable Test Results (Test G) SiX VARIABLES

\begin{tabular}{lcccr}
\hline & & Chi-square & df & \multicolumn{1}{c}{ Sig. } \\
\hline Step 1 & Step & 26.367 & 6 & .000 \\
& Block & 26.367 & 6 & .000 \\
& Model & 26.367 & 6 & .000 \\
\hline
\end{tabular}

Based on the results of the $G$ test it can be seen that the significance value of the model is 0.000 at a significance level of $\alpha=0.05$ so that based on the hypothesis, reject H0 which shows that simultaneously the six variables affect the model. Furthermore, it will be seen how the influence of each independent variable on the dependent variable by conducting a partial test (Wald test).

table IV. Partial Variable Test Results (Test W) Six Variables

\begin{tabular}{ccrrrrrr}
\hline & & \multicolumn{1}{c}{ B } & \multicolumn{1}{c}{ S.E. } & Wald & df & \multicolumn{1}{c}{ Sig. } & $\operatorname{Exp}(\mathbf{B})$ \\
\hline Step & JK & -3.351 & 1.364 & 6.031 & 1 & .014 & .035 \\
$1^{\mathrm{a}}$ & Age & -.287 & 1.229 & .055 & 1 & .815 & .750 \\
& Education & 2.288 & 1.063 & 4.634 & 1 & .031 & 9.853 \\
& Experience & -2.067 & .854 & 5.862 & 1 & .015 & .127 \\
& Time & .491 & .902 & .296 & 1 & .586 & 1.634 \\
& Family & 2.519 & .917 & 7.554 & 1 & .006 & 12.421 \\
& Constant & -1.480 & 1.540 & .924 & 1 & .337 & .228 \\
\hline
\end{tabular}

Based on the results of the partial variable test (Test $W$ ) by looking at the significance value of each variable at the significance level $\alpha=0.05$ it can be concluded that there are variables that have no significant effect on the model because it has a significance value of more than 0.05 . These variables were age variables $(0.815>0.05)$ and the initial age variables for drinking coffee $(0.586>0.05)$. While other variables are gender (0.14), final education (0.31), coffee drinking experience (0.15) and number of family members (0.006) have a significant influence on the model (sig. <0.05).

With the two independent variables that have no significant effect on the model, the two variables will be excluded from the model and logistic regression model will only use four variables[2, 6], namely gender, final education, coffee drinking experience and number of family members that affect consumer preferences for consumption of brewed coffee. or instant coffee [30, 39].

TABLE V. Four VARiable GoOdness Of Fit (Gof) Test Results

\begin{tabular}{crrrr}
\hline Step & Chi-square & Df & \multicolumn{1}{c}{ Sig. } \\
\hline 1 & 3.831 & & 6 & .700 \\
\hline
\end{tabular}

Based on the results of the GoF test can be seen the significance value of hosmer and lameshow test is 0.700 at the level of $\alpha=0.05$ so that based on the hypothesis, accept H0, which indicates that the model is fit or feasible to use because there is no difference between the model and observation. The next test is testing the variables simultaneously by looking at the value of the omnibus test.

TABLE VI. Simultaneous Variable Test Results (G Test) Four VARIABLES

\begin{tabular}{lcccr}
\hline & & Chi-square & Df & Sig. \\
\hline Step 1 & Step & 26.064 & 4 & .000 \\
& Block & 26.064 & 4 & .000 \\
& Model & 26.064 & 4 & .000 \\
\hline
\end{tabular}

Based on the results of the $G$ test it can be seen that the significance value of the model is 0.000 at a significance level $\alpha=0.05$ so that based on the hypothesis, reject $\mathrm{H} 0$, which shows that simultaneously the four variables affect the model. Furthermore, it will be seen how the influence of each independent variable on the dependent variable by conducting a partial test (Wald test).

TABLE VII. Partial VARiable Test Results (Test W) Four VARIABLES

\begin{tabular}{ccrrrrrr}
\hline & & B & S.E. & Wald & df & \multicolumn{1}{l}{ Sig. } & \multicolumn{1}{c}{$\operatorname{Exp(B)}$} \\
\hline Step & JK & -3.354 & 1.371 & 5.982 & 1 & .014 & .035 \\
$1^{\mathrm{a}}$ & Education & 2.224 & .919 & 5.855 & 1 & .016 & 9.244 \\
& Experience & -2.074 & .822 & 6.369 & 1 & .012 & .126 \\
& Family & 2.493 & .890 & 7.841 & 1 & .005 & 12.094 \\
& Constant & -1.190 & 1.459 & .666 & 1 & .414 & .304 \\
\hline
\end{tabular}

Based on the results of the partial variable test (Test $W$ ) by looking at the significance value of each variable at a significance level of $\alpha=0.05$, gender variables (0.014), final education (0.16), coffee drinking experience (0.12) and number of family members (0.005) have a significant influence on the model (sig. <0.05). Based on these results it can be seen that by removing variables that do not significantly increase the significance of each of the other variables. 
TABLE VIII. SUMMARY MODEL

\begin{tabular}{|c|c|c|c|}
\hline Step & -2 Log likelihood & $\begin{array}{c}\text { Cox \& Snell R } \\
\text { Square }\end{array}$ & $\begin{array}{c}\text { Nagelkerke R } \\
\text { Square }\end{array}$ \\
\hline 1 & $46.499^{\mathrm{a}}$ & .367 & .510 \\
\hline
\end{tabular}

The summary model table describes the ability of the independent variable in explaining the dependent variable which is analogous to the R2 value in multiple linear regression. In the table, it can be seen that the value of Nagelkerke R square is 0.510 or 51 percent, which means that the variables of gender, final education, coffee drinking experience, and number of members can explain consumer preferences in choosing instant coffee or instant coffee by 51 percent while the other 49 percent is explained by factors. others that are not in the model [23, 30, 39].

Based on the results of the goodness of fit test, $G$ test, $W$ test, and Nagelkerke $\mathrm{R}$ square it can be concluded that the models used in this study are:

$$
\operatorname{Ln} \frac{\pi_{\mathrm{i}}}{\left(1-\pi_{\mathrm{i}}\right)}=\alpha+\beta_{1}+\beta_{3}+\beta_{4}+\beta_{6}
$$

Before modeling logistic regression by adding independent variables, consumers who had a tendency to consume ground coffee were 38 people while Those who tended to consume instant coffee were 19 people with a model accuracy of 66.7 percent. Based on the model formed, the number of consumers who consumed brewed coffee as many as 38 people in which consumers who actually consume brewed coffee as many as 29 people and who should consume brewed coffee but apparently did not consume as many as 9 people. While consumers who consumed instant coffee as many as 19 people in which consumers who actually consumed instant coffee as many as 13 people and who should consume instant coffee but did not consume as many as 6 people. The accuracy of the model to explain is 73.7 percent.

Gender variables have a significant effect on consumer preferences in choosing coffee $(0.014<0.05)$ [30, 39]. The odds ratio for the sex variable is 0.035 , which means that the chance for consumers of male sex to consume instant coffee is only 0.035 times that of female consumers. Gender variables have a negative relationship with the preference for instant coffee selection which shows that male consumers have greater preference for consuming brewed coffee than women.

The last education variable has a significant influence on consumer preferences in choosing coffee $(0.016<0.05)$. The odds ratio of the last education variable is 9.244 , which means that the opportunity for consumers with the last education of high school (high school) to consume instant coffee is 9,244 times compared to consumers who have junior high school (SMP) and tertiary education. The last education variable has a positive relationship with the preference for instant coffee selection.

The variable of coffee drinking experience has a significant influence on consumer preferences in choosing coffee $(0.012<0.05)$ [30, 39]. The odds ratio of the variable coffee drinking experience is 0.126 , which means that the opportunity for consumers with coffee drinking experience between 11-20 years consuming instant coffee is only 0.126 times that of other consumers. The variable of coffee drinking experience has a negative relationship with the preference of instant coffee selection which shows that consumers with coffee drinking experience between 11-20 years have a greater preference for consuming brewed coffee than other consumers.

Variable number of family members has a significant influence on consumer preferences in choosing coffee $(0.005$ $<0.05)$. The odds ratio variable number of family members is 12,094 which means that the opportunity of consumers who have more than five people in consuming instant coffee is 12,094 times higher than consumers who have fewer than five family members. Variables in the number of family members have a positive relationship with the preference for instant coffee selection.

Opportunities for male consumers with the last level of high school education and having experience drinking coffee between 11-20 years and having a family member of more than five people by 13 percent while others prefer to consume brewed coffee ( 87 percent). Unlike the case with female consumers with the last level of high school education and have experience drinking coffee between 11-20 years and having family members of more than five people have the opportunity to consume instant coffee by 81 percent while the rest prefer to consume brewed coffee (19 percent).

\section{CONCLUSION}

Based on the results of parameter estimation, four variables have a significant effect on consumer preferences, namely gender (sig. 0.014), last education (sig. 0.016), coffee drinking experience (sig. 0.012), and number of family members (sig. 0.005). While the age and early age variables for consuming coffee are discarded from the model because they do not have a significant influence on consumer preferences [30, 39]. This model is suitable for analyzing for coffee consumption because there is no significant difference between the model and the value of the observations. Based on the results of goodness of fit, this model can be used as a logistic regression model to see the opportunities of consumers in consuming brewed coffee or instant coffee. The four independent variables can explain the preference of coffee consumers by 51 percent. Opportunities for adult male consumers with the final education level of high school and the experience of drinking coffee between 11-20 years, as well as the number of family members more than five consuming instant coffee is 0.13 . While the rest prefer to consume brewed coffee. Unlike the case with female consumers who preferred instant coffee with an opportunity for consumption of 0.81 compared to brewed coffee.

\section{POLICY IMPLICATIONS}

A producer must be able to see that the calculation is an opportunity for him to differentiate coffee products owned. 
Processed coffee producers can compete by making a product innovation that can reach all consumers, both men and women. For producers of brewed coffee, producers must be able to innovate to create practical coffee that is easily available both in terms of location and price. For producers of instant coffee, producers must be able to innovate to create instant coffee which tastes not inferior to typical brewed coffee. In this case, producers are required to be creative in creating and presenting products according to the wishes of consumers, especially by drinking coffee is a lifestyle today.

\section{ACKNOWLEDGMENT}

The author would like to thank the Institute of Research and Community Services at the Universitas Pembangunan Nasional "Veteran" Jawa Timur because of the support and opportunities provided so that the writer can produce a scientific work based on the results of research that received funding.

\section{REFERENCES}

[1] H.W. Ibrahim and S.A. Zailani, "Review on the competitiveness of global supply chain in a coffee industry in Indonesia," Int. Bus. Manag., vol. 4, no. 3, pp. 105-115, 2010.

[2] P. Reed and Y. Wu, "Logistic Regression for Risk Factor Modelling in Stuttering Research," J. of Fluen. Disod., vol. 38, pp. 88-101, 2012.

[3] A. Gabriele and D. Vanzetti, "Long Black: Export Controls As A Means of Addressing Coffee Price Instability," J. of Econ. Integr., vol. 23, no. 2, pp. 411-433, 2008.

[4] J. Neilson and F. Shonk, "Chained to development? Livelihoods and global value chains in the coffee-producing Toraja region of Indonesia," Aust. Geogr., vol. 45, no. 3, pp. 269-288, 2014.

[5] A.S. Mohmed, N.B. Azizan, and M.Z. Jali, "The Impact of Trust and Past Experience on Intention to Purchase in E - Commerce," Int. J. of Eng. Res. and Dev., vol. 7, no. 10, pp. 28-35, 2013.

[6] J. Peng, K.L. Lee, and G.M. Ingersoll, "An Introduction to Logistic Regression Analysis and Reporting," J. of Educ. Res., vol. 96, no. 1, pp. 3-14, 2002.

[7] E.S.A.S.A. Offermans and P. Glasbergen, "Sustainability Certification and Economic Performance An Analysis of Coffee Marketing Channels in Indonesia," J. of Econ. and Sustain. Dev., vol. 6, no. 24, pp. 84-98, 2015.

[8] S. P. Shih, S. Yu, and H.C. Tseng, “The Study of Consumers' Buying Behaviour and Consumer Satisfaction in Beverages Industry in Tainan, Taiwan,” J. of Econ., Bus., and Manag., vol. 3, no. 3, pp. 391-394, 2015.

[9] G. Schroth, P. Läderach, D.S.B. Cuero, J. Neilson, and C. Bunn, "Winner or loser of climate change? A modeling study of current and future climatic suitability of Arabica coffee in Indonesia," Reg. Environ. Ch., vol. 15, no. 7, pp. 1473-1482, 2015.

[10] C. Herve and E. Mullet, "Age and Factors Influencing Consumer Behaviour,” Int. J. of Consum. Stud., vol. 33, no. 3, pp. 302-308, 2009.

[11] M. Ibnu, P. Glasbergen, A. Offermans, and B. Arifin, "Farmer preferences for coffee certification: A conjoint analysis of the Indonesian smallholders," J. of Agric. Sci., vol. 7, no. 6, p. 20, 2015.

[12] A. Susanty and E. Kenny, "The relationship between brand equity, customer satisfaction, and brand loyalty on coffee shop: Study of Excelso and Starbucks," ASEAN Mark. J., vol. 1, pp. 14-27, 2015.

[13] M.N. Khuong and H.T.M. Duyen, "Personal Factors Affecting Consumer Purchase Decision Towards Men Skin Care Products: A Study in Ho Chi Minh City, “ Vietnam. Int. J. of Trade, Economics, and Finance, vol. 7(2), pp. $44-50,2014$.
[14] F. Ye, and D. Lord, "Comparing three commonly used crash severity models on sample size requirements: Multinomial logit, Ordered probit and Mixed logit models," Anal. Methods in Accid. Res., vol. 1, pp.7285, 2014.

[15] K. Rahmah, U. Sumarwan, and M. Najib, "The Effect of Brand Equity, Marketing Mix, and Lifestyle to Purchase Decision at Maxx Coffee, Bogor," J. of Consum. Sci., vol. 3(2), pp. 01-15, 2018.

[16] D.N. Gujarati, Basic Econometrics, $4^{\text {th }}$ ed., New York: McGraw - Hill Book Company, 2004.

[17] A.S. Peterson, "Health Benefits of Coffee," The J. of Lanc. Gen. Hosp., vol. 2(4), pp. 1-2, 2007.

[18] Y. Deliana, and I.A. Rum, "Understanding consumer loyalty using neural network," Pol. J. of Manag. Stud., vol. 16, pp. 51-61, 2017.

[19] T. Bagga, and M. Bhatt, "A Study of Intrinsic and Extrinsic Factors Influencing Consumer Behaviour Online," Asia-Pasific J. of Manag. Res. and Innov., vol. 9(1), pp. 77 - 90, 2013.

[20] A. Agresti, An Introduction to Categorical Data Analysis, Toronto: John Wiley and Sons Inc., 1996.

[21] A.I. Baruk, and A. Iwanicka, "The Effect of Age, Gender, and Level of Education on The Consumers' Expectations Towards Dairy Product Packaging," Br. Food J., vol. 118(1), pp. 100-118, 2016.

[22] A. Powell, The Health Benefits of Coffee, Harvard University, [retrieved 3 September 2018].

[23] I. Santoso, "The Analysis of The Role of Instant Coffee Price and Quality in Consumer Preference and Purchasing Decision, in Malang, Using Partial Least Square Method," WACANA, J. Sos. dan Hum., vol. 20(1), pp. 9-14, 2017.

[24] M.H. Kutner, C.J. Nachtseim, and J. Neter, Applied Linear Regression Models $4^{\text {th }}$ Edition. Singapore: The McGraw - Hill Companies Inc., 2004.

[25] J.W. Creswell and J.D. Creswell, Research design: Qualitative, quantitative, and mixed methods approaches, California: Sage publications, 2017.

[26] Sudiyarto, S. Widayanti, and D.M. Kresna. "Perilaku Konsumen Penikmat Kopi Tubruk dan Kopi Instan," J. of Soc. and Agric. Econ., vol. 6, pp. 1-11, 2012.

[27] Ferdinand, Metode Penelitian Manajemen: Pedoman Penelitian Untuk Skripsi, Tesis, dan Disertasi Ilmu Manajemen, Semarang: Badan Penerbit Universitas Diponegoro, 2002.

[28] D.W. Hosmer and S. Lameshow, Applied Logistic Regression, 2nd ed., New York: John Willey and Sons, 2002.

[29] N. Ramya and M. Ali, "Factors Affecting Consumer Buying Behaviour,” Int. J. of Appl. Res., vol. 2, pp. 76-80, 2016.

[30] C. Mongkol, "Analyzing Factors That Drive Consumer Preferences On Franchised Coffee Shops In Manado," J. Riset Ekon., Manaj., Bis. dan Akunt., vol. 4, 2016.

[31] G. Vanithamani, "A Study on Impact of Educational Disparity on Consumer Buying Behaviour and Perception Towards Selected ITC Products With Particular Reference to Coimbatore City," Int. J. of Commer. and Manag. Res., vol. 31(2), pp. 74-77, 2017.

[32] H. Elly, "Fenomena Coffee Shop Sebagai Gejala Gaya Hidup Baru Kaum Muda," J. Bhs., Peradab., dan Inf. Islam, vol. 13(1), pp. 1-18, 2012.

[33] S. Kanaka and M. Chinadurai, "A Study of Comparative Advantage of Indian Agricultural Exports," J. of Manag. and Sci., vol. 2(3), pp. 1-9, 2012.

[34] S.E. George, K. Ramalakshmi, and L.J.M. Rao, "A Perception on Health Benefits of Coffee," Food Sci. and Nutr., vol. 48(5), pp. 464-486, 2008.

[35] G. Imam, Aplikasi Analisis Multivariate Dengan Program SPSS, Semarang: Badan Penerbit Universitas Diponegoro, 2005.

[36] Y.N. Lukito and A.P. Xenia, "Experiencing contemporary cafés and changes in the characteristic of third places," Earth and Env. Sci., vol. 126(1), pp. 012208, March 2018.

[37] W.H. Lire, "Review on Health Benefit and Risk of Coffee Consumption," Med. and Arom. Plants, vol. 6(4), pp. 1-12, 2017. 
[38] R.G. Apaza, C.E. Portugal-Zambrano, J.C. Gutiérrez-Cáceres, and C.A. Beltrán-Castañón, "An approach for improve the recognition of defects in coffee beans using retinex algorithms," IEEE Comput. Conf., vol. 15, pp. 1-9, September 2014.

[39] D. Asioli, T. Næs, B.S. Granli, and V.L. Almli, "Consumer preferences for iced coffee determined by conjoint analysis: an exploratory study with Norwegian consumers," Int. J. of Food Sci. and Technol., vol. 49(6), pp. 1565-1571, 2014.

[40] G. Messina, C. Zannella, V. Monda, A. Dato, S.D. Blasio, A. Valenzano, F. Moscatelli, A. Messina, G. Cibelli, and M. Monda, "The Beneficial Effects of Coffee in Human Nutrition," Biol. and Med., vol. 7(4), pp. $1-5,2015$.

[41] K. Rahmah, U. Sumarwan, and M. Najib, "The Effect Of Brand Equity, Marketing Mix, And Lifestyle To Purchase Decision At Maxx Coffee, Bogor," J. of Consum. Sci., vol. 3(2), pp. 1-15, 2015.

[42] I. Said, P. Hijjang, C.I. Musa, and S. Samad, "The Lifestyle of The Urban Community, A Study on Coffee Lovers In Excelso Coffee Shop," Int. J. of Acad. Res., vol. 7, 2015.

[43] R. Aryani, R. Arifianti, and M. Purnomo, "Factors Affecting Impulse Buying in Alfamart Customers in Ujungberung Sub-District, Bandung," Adv. in Soc. Sci. Rese. J., vol. 5(8), 2018.

[44] P. Kotler and G.M. Armstrong, Marketing Mix: Selected Chapters From: Principles of Marketing, Pearson: Philip Kotler and Gary Armstrong, 2018.

[45] W. Akhtar and M. Husnain, "Factor That Effect on Cinsumer Behaviour: The Case of Boarding Students," J. of Progres. Res. in Soc. Sci., vol. 2(2), pp. 71-79, 2015
[46] M.A.H. Saleh, B. Alothman, and L. Alhoshan, "Impact of Gender, Age, and Income on Consumers' Purchasing Responsiveness to Free-Product Samples,” Res. J. of Int. Stud., vol. 26, pp. 83-94, 2013.

[47] J. Neilson, J. Wright, and L. Aklimawati, "Geographical indications and value capture in the Indonesia coffee sector," J. of Rural Stud., vol. 59, pp. 35-48, 2018.

[48] G. Schroth, P. Läderach, D.S.B. Cuero, J. Neilson, and C. Bunn "Winner or loser of climate change? A modeling study of current and future climatic suitability of Arabica coffee in Indonesia," Reg. Env. Chang., vol. 15(7), pp. 1473-1482, 2015.

[49] V. Nelson, J. Haggar, A. Martin, J. Donovan, E. Borasino, W. Hasyim, N. Mhando, M. Senga, J. Mgumia, E. Quitanar-Guadarrama, and Z. Kendar, "Fairtrade Coffee A study to assess the impact of Fairtrade for coffee smallholders and producer organisations in Indonesia, Mexico, Peru, and Tanzania," [Online], Available: https://www.maxhavelaar.ch/ fileadmin/CH/Was_ist_Fairtrade_/Wirkungsstudien/2016_NRI_Coffee_ Impact_Assessment.pdf. [Accessed: 28-Aug-2018]

[50] S.V. Archontoulis and F.E. Miguez, "Nonlinear regression models and applications in agricultural research," Agron. J., vol. 107(2), pp. 786 798, 2015.

[51] F.S. Rumokoy, "Evaluating The Service Quality Of Coffee Shop In Manado Using Importance And Performance (Ipa) Analysis.(Case Study: Excelso Coffee)," J. of Asean Stud. on Marit. Issues, vol. 2(2), pp. 16-28, 2018

[52] N.A. Febrianto, K. Sa'diyah, and T. Tejasari, "Red Kidney Bean Powder Substituted Milk in Cinnamon Herbal Coffee: Consumer Perception, Sensory Properties and Nutrition Content," Pelita Perkebunan, vol. 32(2), pp. 109-119, 2016 